\section{LEVEL OF SATISFACTION OF PHYSIOTHERAPISTS WITH REGARDS TO THEIR PROFESSION}

\section{ABSTRAC}

\section{OBJECTIVE}

The aim of this study was to investigate the level of satisfaction among physiotherapist with regards to their profession

STUDY DESIGN

nal survey was conducted.

STUDY SETTINGS \& PARTICIPANTS

The data was collected from 450 physical therapists with recognized degrees of
BPT PPDPT and Masters in Physical Therapy Data was collected from 5 tertion care hospitals, 6 clinics and privately practicing Physiotherapists in Karachi.

RESULT

The results shows that 70\% physiotherapist somewhat satisfied with their generd working conditions. When assessed the barriers face during the
to gender it was observed that neutral responses were reported.

CONCLUSION

The finding shows that the physiotherapists are moderately satisfied with their obs.

Keywords

Job Satisfaction, Physical Therapist, Genera
tion, Work Relationship, Skills and Abilities 2013:2(2):27-31]

\section{INTRODUCTION}

In recent years, physiotherapists have been increasingly interest od this interest lies a fundamental question at the the role of Physiotherapist in the field of Medicine and their standing as physiotherapy professionals. Physical medicine or physical therapy has very ancient origins. For were treated with various methods making use movements (with or without the aid of mechanica devices) as well as air, water, heat and cold, electricity and light. Despilie is long history, however, astonishing little historical research

Elements of physiotherapy practice can be traced to ancient China, Greece, and Rome, with significan in the nineteenth century. Australian physiotherapy has it origins in the United Kingdom (UK) where, in 1894, an Association was formed by members of its precursor discipline-massage therapy. The growth of the and migratory links to the $\mathrm{UK}^{2}$. The roots of the physica therapist education reach back through the ages. The profession of physical therapy may have begun as early massage. The development of physical therapy as an autonomous profession based on current scientific sweden. Thereafter, physiotherapy education evolved different ways around the world. In the UK, it was throug it was influenced by the work of Ling, with an emphasis on massage training. In the United States, it was as a result of the polio epidemics and the need to treat those

As a profession integral to health promotion, prevention acute care and rehabilitation physiotherapy plays an explore the current nature of physiotherapy, the tant to physiotherapy in health care the physiotherapy internationally, the education of physiotherapists, the regulation of physiotherapy practice or every Physiotherapist to know the depth of the profession and to understand their strengths and weaknesses for the professional growth and satisfaction 4 Physiotherapist, as professionals have a genera egarded in comparison to other medical and allied health care professions. It is a dilemma that despite of such a historic background and strong connection with capitalize on our education and training to bechable to expand our profession nationally and internationally. Physiotherapists are constrained by a lack of clarity abou

Physiotherapy education right from the entry-level is vito n providing a base to prosper and develop. Education of students within the allied health professions aims to equip sional behaviors to work safely and competently contemporary health care professionals. Broadly, clinica education involves learning clinical and professional skills in the workplace $e^{6}$. This provides students with the opporpractice knowledge, to socialize into a profession practice community and to understand the complexities theallh care delivery $y^{310}$. Awareness of inter-professional

Another reason that can be cause to reduce the satisfaction of physiotherapist towards their profession is the job stress which increases the risk for a variety of daverse outcomes. These outcomes include burnout,
turnover, sickness absence, Work-related musculoskeletal disorders (WMSDS) and other medical conditions $12-16$. According to Higashiguchi, physiotherapists are invalua-
ble assets to the hospitals and institutions where they ble assets to the hospitals and institutions where they
practice. Yet the increase job turnover among physiopractice. Yet the increase job turnover among physio-
therapists is a reason for concern. Whether these reasons are economic or otherwise, they all give basis for seeking employment elsewhere. Increase workload leading to burnout may be another contributing factor as to why

Journal of occupational health represents that most physiotherapists work in hospital while the other works in private clinics or rehabilitation centers. Among physiotherapist the level of job satisfaction was not known, ob satisfaction and to identify the barriers of job satisfaction among physiotherapist. If the job satisfaction level and the barriers are identified important actions can be quently overcome the barriers's.

There is a general perception that flexible work hours will report higher levels of organizational commitment and increased job enrichment and autonomy reduced tardiness and absenteeism, and improved job satisfaction and productivity. But at the same time the major slisadvantages identified include costs, problem with vising all employees on flexible work hours, and changes in the organizational culture 19. Poor salary structure is also key factor of job satisfaction therapist with low salary will dishearten and could not perform his and aties with rys be on the other hand they also support their families in physiotherapy profession there is a big gap for develop-

Healthcare system has remained a neglected meadow When job satisfaction is evaluated. Lesser work has been account. Increase turnover and discontinuation of their
acosition srive and factors which are acting as bariers need to be evaluated. Research in this context is few and in our part of the world no appreciable work is done. Therefore this sudy will be undertaken to assess the ba. hers leading to

MATERIALS AND METHODS Study Design

y was conducted.

Sampling Technique

u non-probability convenient sampling technique was

[Usman R, Nafees F, Farooqui SI, Physiotherapists with Regards to their Profession. Pak. j. rehabil.
Study Setting and Participants recognized degree of physical therapy. Physiotherapist 
working at 5 tertiary care hospitals, 6 clinics and privately practicing physiotherapists were selected.

Study Duration

The data was collected over a period of 12 months.

Inclusion Criteria

Physiotherapists who are qualified with recognized degree
2.

Exclusion Criteria

1. Non responsive participants.

Physiotherapist absent at the time of data terns.

\begin{tabular}{|c|c|}
\hline Age & (Mean \pm Sd) \\
\hline Years & $28.86 \pm 5.19$ \\
\hline Gender & $\mathrm{n}(\%)$ \\
\hline Male & $195(43.3)$ \\
\hline Female & $255(56.7)$ \\
\hline $\mathrm{N}$ & 450 \\
\hline Qualification & $\mathrm{n}(\%)$ \\
\hline BPT & $201(44.5)$ \\
\hline Masters & $198(43.5)$ \\
\hline PPDPT & $51(12)$ \\
\hline $\mathrm{N}$ & 450 \\
\hline
\end{tabular}

\section{Data Collection Procedure}

Physiotherapists were approare was used to collect data work and after explanation of the objectives of research Questionnaire consisted of three portions corresponding to demography, barriers, and assessment of satisfaction
levels. The Physiotherapist that fuffilled the inclusion were asked to fill the forms. Data collected was entered and analyzed on SPSS version 20. Relevant descriptive statistics was taken out depending on the type of variable under the study. P value less than 0.05 was considered os

\section{Ethical Consideration}

Informed consent will be taken from all participants after ERB clearance will be taken before start of data collec-

\section{RESULTS}

The level of satisfaction of physiotherapist towards the profession was assessed through a survey questionnaire. that filled the questionnaire based on their own perception and experience regarding their profession
The average age group was $28.8 \pm 5.2$ out of which $43.3 \%$ were males and $56.7 \%$ females. Approximately $44.5 \%$ of the respondents were Bachelors in Physical Therapy and the other $43.5 \%$ and $12 \%$ completed their masters and PPDPT respectively. For the general working condition, as
it is one of the assessment tools for evaluating the level satisfaction in this survey we compiled four characteristics: working hours each week, flexibility in scheduling, location of work, amount of paid vacation time/sick leave offered. Among 450 individuals $72.9 \%$ people were somewhat satistied while $17.6 \%$ were
When asked about the flexibility in scheduling $70.7 \%$ were
somewhat satisfied and $16.4 \%$ respondents were extremely satisfied. $72.7 \%$ respondents were some what satisfied with their location of work. In response of $51.3 \%$ with their paid somewhat satisfied for all four characteristics of general working condition.

walle physiolow salary structure.

It has been noted that $42.6 \%$ male and $27.8 \%$ female strongly disagreed with the issue close proximity with
patient while $24.6 \%$ male and $25.1 \%$ females disagreed. In response of moving heavy clients as barrier $46.7 \%$ male and $27.5 \%$ female strongly disagree, while $7.2 \%$ male and 14.5\% females were strongly agree.

When ask about the poor salary structure in comparison trongly disagremale $5.2 \%$ male and $3.9 \%$ females were have neutral opinion about their salary structure.

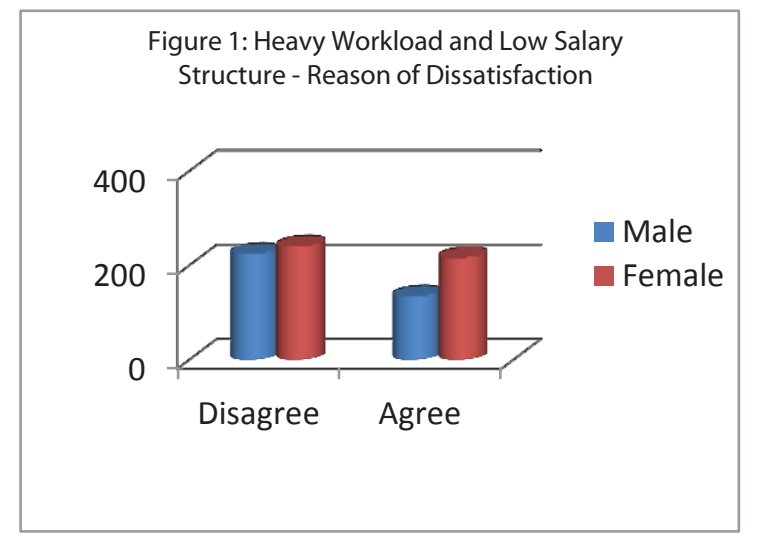

When asked about pay and promotion potential $33.6 \%$
people were not satisfied at all with their salary. While people were not satistied at all with their salary. While
$46.0 \%$ responded that they were somewhat satisfied with the opportunities for promotion. $46.9 \%$ were not satisfied at all with benefits (paid vacations, health insurance)
when ask about the job security $47.8 \%$ respondents were When ask about the job security $47.8 \%$ respondents were
not satisfied at all while $54.2 \%$ respondent were somewhat satisfied with work accomplishment.

When physiotherapists were asked about their general ly satisfied with their field. The level of satisfoction was assessed to be low moderate or high. Among 450 participants, $22.22 \%$ of the physiotherapists had low satisfaction levels and $20 \%$ had high level of satisfaction. Interestingly,
$57.77 \%$ had moderate level of satisfaction in regards to Figure 2: General Perception of

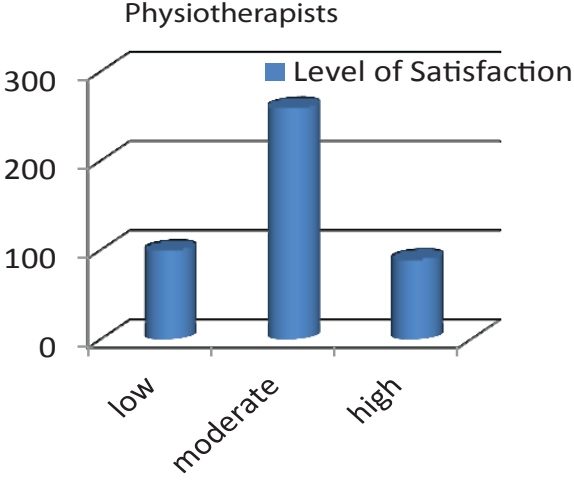

\begin{tabular}{|c|c|}
\hline \multicolumn{2}{|c|}{$\begin{array}{l}\text { Table 2: Pay and Promotion Potential - Source o } \\
\text { Satisfaction }\end{array}$} \\
\hline Salary & $\mathrm{n}(\%)$ \\
\hline Not satisfied at all & $151(33.6)$ \\
\hline Somewhat satisfied & $250(55.6)$ \\
\hline Extremely satisfied & 49 (10.9) \\
\hline $\mathrm{N}$ & 450 \\
\hline \multicolumn{2}{|c|}{ Opportunities for Promotion } \\
\hline Not satisfied at all & $196(43.6)$ \\
\hline Somewhat satisfied & $207(46.0)$ \\
\hline Extremely satisfied & $47(10.4)$ \\
\hline $\mathrm{N}$ & 450 \\
\hline \multicolumn{2}{|c|}{$\begin{array}{l}\text { Benefits (Paid leaves, Health } \\
\text { insurance etc) }\end{array}$} \\
\hline Not satisfied at all & $211(46.9)$ \\
\hline Somewhat satisfied & $193(42.9)$ \\
\hline Extremely satisfied & $46(10.2)$ \\
\hline $\mathrm{N}$ & 450 \\
\hline \multicolumn{2}{|l|}{ Job Security } \\
\hline Not satisfied at all & $215(47.8)$ \\
\hline Somewhat satisfied & $184(40.9)$ \\
\hline Extremely satisfied & $51(11.3)$ \\
\hline $\mathrm{N}$ & 450 \\
\hline \multicolumn{2}{|l|}{$\begin{array}{l}\text { Recognition for work } \\
\text { accomplished }\end{array}$} \\
\hline Not satisfied at all & $158(35.1)$ \\
\hline Somewhat satisfied & $244(54.2)$ \\
\hline Extremely satisfied & $48(10.7)$ \\
\hline $\mathrm{N}$ & 450 \\
\hline
\end{tabular}

\section{DISCUSSION}

in this survey, we assessed different dimensions of the physiotherapy profession in terms of general working
conditions, pay and promotion potential, work relation
ships, use of skills and abilities and barriers were evaluated. Results revealed that physiotherapist have moderate studies $\mathrm{S}$ Bodur and $\mathrm{H}$ Sur, concluded the global job satisfaction measured by a single item questionnaire and indicate that over $50 \%$ of the physiotherapists were dissaconstant with the other studies on job satisfaction amon health care providers in Turkey ${ }^{2223}$.

A study was carried out within the framework of occupapy relative to a range of professions, including a number from the medical field. The results indicate that physioherapy possesses an intermediate stalus, and one the the two professions are virtually indistinguishable on most of the dimensions employed in the study. The results also eveal the position of physiotherapy relative to the nursing

other studies, job stress has been linked to medical and psychiatric conditions, including depression and cardiac disease. In health care workers, job stress has been linked demonstrated that physical therapists may experience
Different dimensions of work stress have been studied in physical therapists, but common themes have emerged. Common sources of work stress have included excessive west sional culture in physical therapy may complicate the work environment. Physical therapists hold themselves to high professional standards and may experience a the face of external pressures including increasing workloads and job demands, job stress may be viewed as a personal failing ${ }^{29,313,32}$.

Grembowski $D^{33}$, Bovier $\mathrm{PA}^{34}$, and Seo $\mathrm{Y}^{35}$ in their studies show that there is a strong correlation between income strated in Turkey that income and working conditions were main factors for dissatisfaction for health care
providers's2. Our study also highlighted the fact that the opportunities for persona and professional growth were one of the best forecaster of job satisfaction.

According to Japanese physical therapy association, clinician with more than 15 years of working experience who work 24 to 32 hours work each week on OPD having largest number. The white paper said that the therapist number, if they have more working expere These differences shows therapist who have more than 10 year of working experience may not feel over work because they are self-assured in their work.

This research identified the expression of wishing to stay Within the organization for a bright future and the percep-
tion of stability or job security as a general indicator of job tatisfaction and stress. Both ant as they were significantly related to the effort and
reward imbalance of the rehabilitation staffs's affected by the work load and number of patients that the therapists have to treat per day.

\section{CONCLUSION}

his study provides information about the status of general and dimensional specific job satisfaction among a group of physiotherapist who practice in Karachi, Pakistan. The satisfied with their jobs. Working conditions, promotional potentials, interpersonal relationship, salary and advancement are the best predictors of job satisfaction among physiotherapisits. Specific job satisfaction dimenthe area of salary and opportunity for professional

\section{REFERENCES}

(1] Chipchase LS, Galley P, Jull G, McMeeken JM, years of physiotherapy education in Australia. Australian Journal of Physiotherapy 2006 Vol. 52 Education around the World. Journal of Physical Therapy Education 2012;26(1):13
Terlouw TJA. Roots of Physical Medicine, Physical Terlouw TJA. Roots of Physical Medicine, Physical
Therapy, and Mechanotherapy in the Netherlands in the 19th Century: A Disputed Area within the
Healthcare Domain. J Man Manip Ther 2007:15(2): E23-E41.

[4] Higgs J, Refshauge K, Ellis E. Portrait of the physioof Inter-professional Care 200

5] You L, Sadler G, Majumdar S, Burnett D, Evans $C$. 
Physiotherapists' Perceptions of Their Role in the Rehabilitation Management of Individuals with

[6] Chipchase L, Dalton M, Williams M, Scutter S. ducation immune from evidence-based scrutiny? Aust J Physiother 2004:50(3):133-135.

Lekkas P, Larsen T, Kumar S, Grimmer K, Nyland L, Chipchase L, et al. No model of clinical education systematic review. Aust J Physiother 2007:53(1):19-28

8] Ferguson K, Edwards H. Providing clinical education: the relationship between healih and education. Health Professional Education. Ed: Higg L. Edward E. Oxford: Butterworth Heinemann 1999:52-60.

[9] Delany C, Bragge P. A study of physiotherapy Ded Teach 2009:31 (19):E402-E4

(10] Ernstzen DV, Bitzer E, Grimmer-Somers K. Physiotherapy students and Elinical teachers percepilions of elinical learning opportunities: a case study. Med

Smith M, Higgs J. (Eds) Trends in fieldwork education. Rotterdam L: Sense Publishers;2010.

[12] Escriba-Aguir V, Martin-Baena D, Perez-Hoyos S. Pychos Arch Occup Environ Health 2006:80:127-133.

Ahola K, Hakanen J. Job strain, burnout, and depressive symptoms: a prospective study among

[14] de Croon EM, Sluiter JK, Blonk RW, Broersen JP. Frings-Dresen MH. Stressful work, psychological job strain, and turnover: a 2-year prospective cohor
study of truck drivers. I Appl Psycho

[15] Head J, Kivimaki M. Martikainen P. Vahtera J, Ferrie $J E$, Marmot MG. Influence of change in psychosocial work characteristics on sickness absence: the 2006: 60 (1):55-61. J Epidemio

Krause N, Ragland DR, Fisher JM, Syme SL. Psychosocial job factors, physical workload, and incidence of work-elated spinal injury: a 5-year prospective study of Urban

17] Higashiguchi K, Morikawa Y, Miura K, Nishijo M, Tabata M, Yoshita K, et al. Review and Develop Inventory and its factors. Jpn J Hygiene Eker L. Tüzün EH (in Japanese). of job satisfaction among physiotherapist among Turkey. J Occup Heallh 2004,46(6).500-5.

and behavioral consequences of flexitime. Journa of applied psychology 1982;67(2):214-218.

[20] Pierce JL, Newstorm JW. The design of flexible work schedule and employee responses; Relation and process. Journat
1982:4:247-262.
[21] Rainey GW, Wolf L. Summer (1982) the organizationally dystunctional consequences of flexible work
hours: A general Overview. Public Personne management journal 1982; $11: 165-175$.
marsonne

[22] Bodur S. Job satisfaction of health care staff employed at health centers in Turkey. Occup Med (Lond) 2002:52(6): 353-355.23] Sur H, Hayran O, Mumcu $G$, soylemez $D$, Afli $H$ and Yildirim $C$. cross-sectional survey in Turkey. Eval health Prof 2004:27(2):152-164

[24] Whitfiel TWA, Allison I, Laing A, Turner PA. Percepthins of the physiotherapy profession: A compara-

[25] Blackmore ER, Stansfeld SA, Weller I, Munce Lagorski BM, Stewart DE. Major depressive episodes and work stess. resuls thom a national population Bourbonnais $R$, Vézina $M$, et al. Job strain and risk of acute recurrent coronary heart disease even

77] Williams ES, Manwell $1 B$, Kong. relationsh fion, and burnout with physician-reported error and suboptimal patient care. results from the MEMO 2007:32(3):203-212.

[28] Park JR, Coombs CR, Wilkinson AJ, Clarke JL, Arnold J, Preston D. Attractiveness of physiotherapy in the
National Health Service as a career choice: qualitaNational Healfh Service as a career choice. quallta

[29] Broom JP. Williams J. Occupational stress and nevelogical rehabilitation physiotherapists. Physiothera-

Py 1996:82 (11):606-614.
[30] Schuster ND, Nelson DL, Quisling C. Burnout among 11 Deckard GJ, Present RM. Impact of role stress on physical therapists' emotional and physical well-being. Phys Ther 1989;69(9):713-718.

Blau therapy in a changing health care environment. Phys Ther 2002;82(7):648-657.

[33] Grembowski D, Ultrich CM, Paschane D, Diehr ky physician satisfaction $\perp$ Am Board Fam Pract 2003:16(5):383-393.

[34] Bovier PA, Perneger TV. Predictors of work satisfac tion among physician

[35] Seo Y, Ko J, Price JL. The determinants of job salisfaction among hospital nurses: model estima tion in Korea. Int J Nurs Stud 2004;41 (4):437-446.

assistants and other no physician provish ician managed care setting. Public Health Rep 1995;110(6):714-719.

\section{ASSOCIATION OF PROLONG SITTING WITH COMMON MUSCULOSKELETAL DISORDERS AMONG PRIVATE AND PUBLIC SECTOR BANKERS}

\section{ABSTRAC}

o compare the frequency of common musculoskeletal disorders due to STUDY DESIGN

\section{STUDY SETTINGS \& PARTICIPANTS}

year were inducted in the study All bankers were divided into private one public sector groups. Employees were selected from private sector and public

DATA COLIECTION TOOL

sectors.

RESULTS

The study shows that $44.6 \%$ government employees were suffering from shoulder
pain, while $36.9 \%$ private sector bankers having this problem. Among then $18.2 \%$ of public sector bankers suffered from neck pain. However, only $9 \%$ of

CONCLUSION

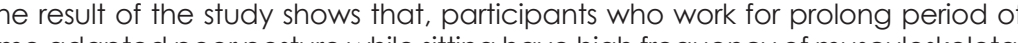
time adapted poor posture while sitting have high frequency of musculoskeletal about their health and posture as compared to the public sector bankers.

Mahmooda Naqvi Lauddin Univege of Physical Therapy mahmoodanaqvi@hotmail.com

Maryum Zehra

herapist Civil Hospital

Ghazala Noor Nizam

Ziauddin College of Physical Therapy

Ziauddin University

gazi_17@hotmail.com
[Naqvi M, Zehra M, Nizami GN. Association of prolong sitting with common musculoskeletal disorders among 